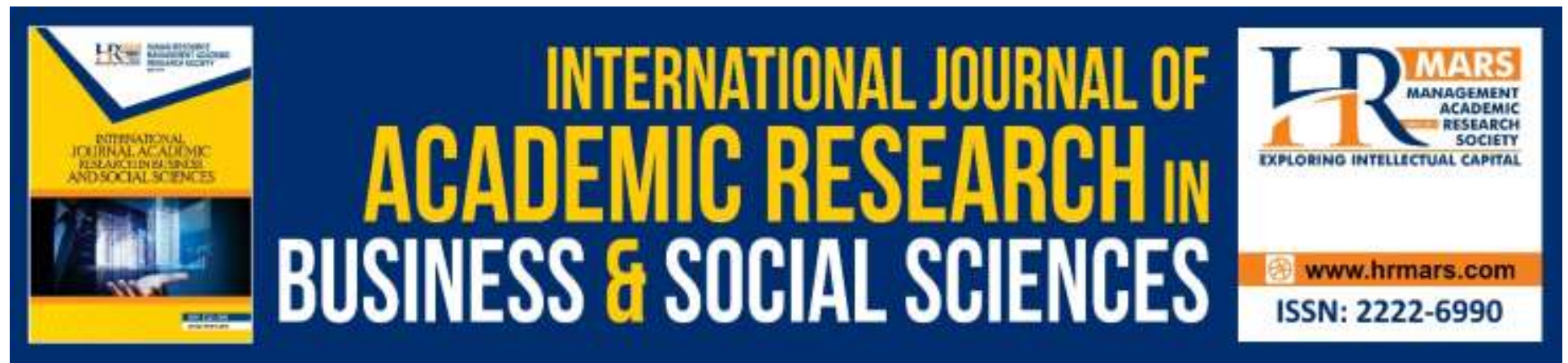

\title{
2D CAD Engineering Drawing for Industrial Design: Furniture and Products Designed by Students
}

Indera Irawan Mohd Rawi, Gunasegaran Karuppannan, Khatipah Abd Ghani

To Link this Article: http://dx.doi.org/10.6007/IJARBSS/v10-i2/7015 DOI:10.6007/IJARBSS/v10-i2/7015

Received: 20 January 2020, Revised: 01 February 2020, Accepted: 12 February 2020

Published Online: 29 February 2020

In-Text Citation: (Rawi et al., 2020)

To Cite this Article: Rawi, I. I. M., Karuppannan, G., \& Ghani, K. A. (2020). 2D CAD Engineering Drawing for Industrial Design: Furniture and Products Designed by Students. International Journal of Academic Research in Business and Social Sciences, 10(2), 847-859.

Copyright: (c) 2020 The Author(s)

Published by Human Resource Management Academic Research Society (www.hrmars.com)

This article is published under the Creative Commons Attribution (CC BY 4.0) license. Anyone may reproduce, distribute, translate and create derivative works of this article (for both commercial and non-commercial purposes), subject to full attribution to the original publication and authors. The full terms of this license may be seen at: http://creativecommons.org/licences/by/4.0/legalcode

Vol. 10, No. 2, 2020, Pg. 847 - 859

http://hrmars.com/index.php/pages/detail/IJARBSS

JOURNAL HOMEPAGE

Full Terms \& Conditions of access and use can be found at http://hrmars.com/index.php/pages/detail/publication-ethics 


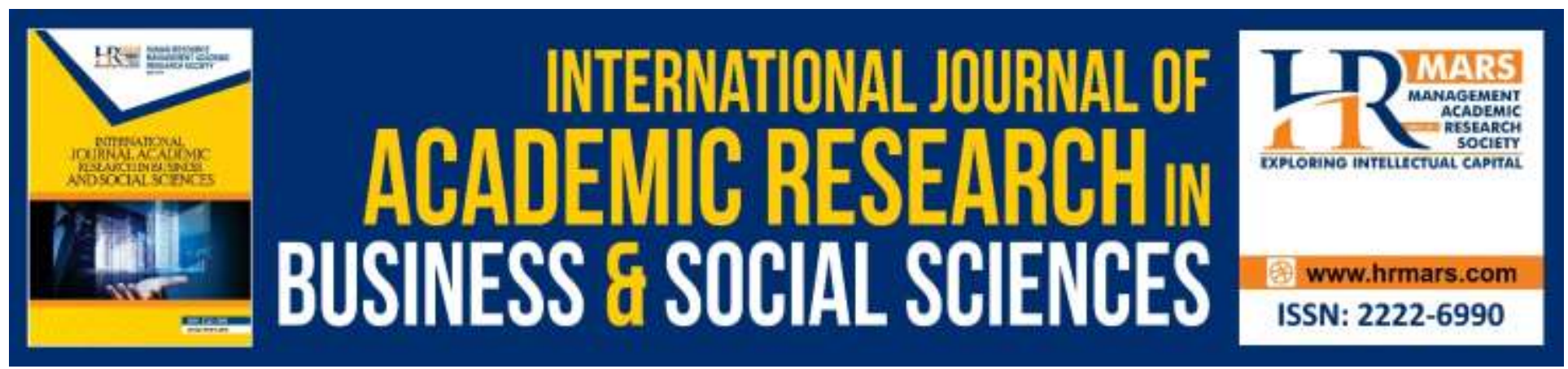

\title{
2D CAD Engineering Drawing for Industrial Design: Furniture and Products Designed by Students
}

\author{
Indera Irawan Mohd Rawi, Gunasegaran Karuppannan, Khatipah \\ Abd Ghani
}

Email: indera.chandran@firstcity.edu.my,drguna@unisel.edu.my, khatisj@unisel.edu.my

\begin{abstract}
Numbers of industry practitioners have commented that graduates have failed miserably in producing quality 2D CAD engineering drawing. Therefore, the purpose of this study is to identify the correlation between root of problems and competency in using the 2D CAD software program. The data were gathered from literature review analysis and semi- structured interview sessions held with several selected furniture and product design lecturers. The findings pointed out that certain skills pertaining to spatial visualization, knowledge on STEM, software interface design, and personal perspectives (attitudes) were required to attain competency in 2D CAD engineering drawing.
\end{abstract}

Keywords: 2D CAD, Engineering Drawing, Furniture and Product Design, Competency

\section{Introduction}

The 2D CAD is a software application that generates 2 dimensional (2D) drawing model, drafting, and engineering drawing. This software program was introduced to furniture and product design courses (FPD), as well as other design courses, in order to help students in delivering technical drawings before proceeding to model development stage. However, the lack of competency in technical drawing among the present graduates has failed them in satisfying industry demands (Burvill, Field, Abdullah, \& Alias, 2016). In fact, some of the common outcomes detected in the drawings produced were misread or wrongly drawn, and non-workability. This issue, in turn, can lead to increment in the rate of non-employability among graduates.

\section{Objective}

- Identify the correlation between root of problems and competency in using the 2D CAD software program.

- Make improvement on the industrial design modules. 
INTERNATIONAL JOURNAL OF ACADEMIC RESEARCH IN BUSINESS AND SOCIAL SCIENCES Vol. 10, No. 2, Feb, 2020, E-ISSN: 2222-6990 @ 2020 HRMARS

\section{D CAD Engineering Drawing}

$C A D$ is a software program used to generate engineering drawings. As such, the $2 D C A D$ engineering drawing embedded in FPD courses mostly focus on orthographic drawing, sectional views, fitting, and joining parts. Nonetheless, to date, the 3D CAD software program, in which one can produce 3D drawings, can also be applied to automatically develop 2D orthographic drawing simultaneously. Nonetheless, several 3D software programs still demand 2D drawing before generating 3D drawing. Hence, designers or students cannot escape from 2D engineering drawing, especially when conventional drawing is involved. Therefore, CAD users must comprehend and be knowledgeable in conventional drawing. Through conventional drawing, one can learn the fundamental of engineering drawing that employs technical drawing instruments. In fact, 3 types of 2D engineering drawings are available, which are: geometric construction, orthographic projection drawing, and sectional drawing. Thus, one should be able to construct geometrical figures in producing accurate drawings.

On top of that, one must also possess knowledge regarding standard engineering drawing format, for example, the International Federation of the National Standardizing Associations (ISO), the American National Standards Institute (ANSI), the British Standards Institution (BSI), and the Australian Standard (AS1100). Besides, all the drafting standards mentioned above mostly apply similar formats and symbols in the drawings (Brunner, Ullrich, Jungen \& Esch, 2016).

Moreover, the users should also emphasize on both dimensions and tolerance due to their importance for manufacturers to read those drawings and to proceed with producing prototypes. With that, the user cannot escape from having sufficient knowledge concerning mathematics and materials sciences (Eteli \& Eniekenemi, 2016). Other than that, strong spatial visualization skills are also essential to visualize drawings in 3D. In fact, the skill of spatial visualization refers to a vital cognitive skill linked to the arena of science, technology, engineering, and mathematics (STEM) (Hafizan, Shahali \& Halim, 2017).

\section{Competency}

The process of teaching and learning denotes the acquisition of knowledge, skills, and attitudes that significantly enhances performance within one's competency level (Chouhan \& Srivastava, 2014). Figure 1 illustrates the correlations of ability or competence with several other important elements, which are skill, knowledge, and attitude. Besides, the term 'competency' reflects one's characteristic in demonstrating skill, possessing knowledge, and displaying optimistic attitudes, which could generate positive outcomes within the occupational area. Similarly, it also refers to the behavior that derives from the aspect of performance.

As such, several areas within the element of competency in relation to engineering drawing demand improvement. For instance, 2D CAD is a tool that is comprised of numerous commands, although not all are functional for FPD. Hence, it is important to determine the primary commands that are frequently used for FPD 2D engineering drawing. Besides, simple and non-intricate commands should ease students to memorize and to utilize the CAD software program. 


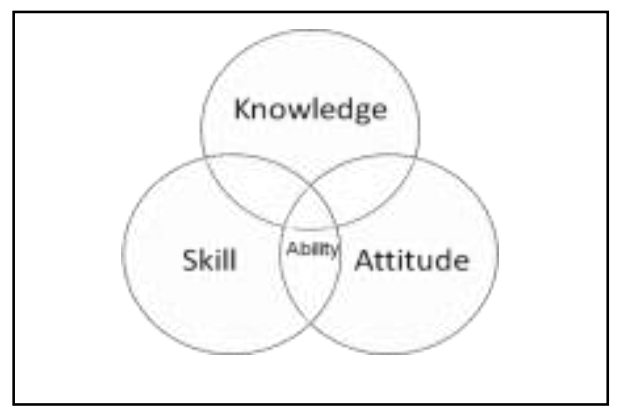

Figure 1. The three components of Competency.(Chouhan \& Srivastava, 2014)

Furthermore, quality outcomes depicted from engineering drawing have to be brought into limelight. Hence, it is imminent for students to reck on how, when, and where to apply appropriate line weight, type of line, and hidden line in the 2D engineering drawing. Unfortunately, several elements have been found missing for line quality (Giesecke et al., 2016).

Meanwhile, technical thinking skills, which involve knowledge of mathematics and spatial visualization, cannot be neglected as they too are associated to engineering drawing. Reviews of literature do not reflect summaries alone, but also viable arguments and research gaps that need to be bridged (Bychedi, 2015). On top of that, reviews of literature aid in identifying appropriate methodologies that could be applied to address particular issues (Creswell, 2017), besides guiding a lost researcher to determine the key questions that revolve around a topic for further research.

With that, this paper had identified four categories associated to competency, which are classified within three compartments of competency. For instance, spatial visualization is categorized under the aspect of skills primarily because all engineering drawings demand spatial visualization skills to draw multiple views, either in 2D or 3D form (Efer, 2017) . On the other hand, STEM subjects and use of software interface are grouped into the knowledge compartment. This means that one should be knowledgeable in the related theories, besides being able to memorize both subjects and software menu (Stefanova \& Vasileva, 2014). Meanwhile, the element known as 'personal behavior', which reflects one's character pertaining to 2D engineering drawing, is perched in attitude compartment. This particular aspect taps into motivation and creative thinking that are required in generating drawings. Figure 2 portrays the literature review analysis framework. 
INTERNATIONAL JOURNAL OF ACADEMIC RESEARCH IN BUSINESS AND SOCIAL SCIENCES Vol. 10, No. 2, Feb, 2020, E-ISSN: 2222-6990 @ 2020 HRMARS

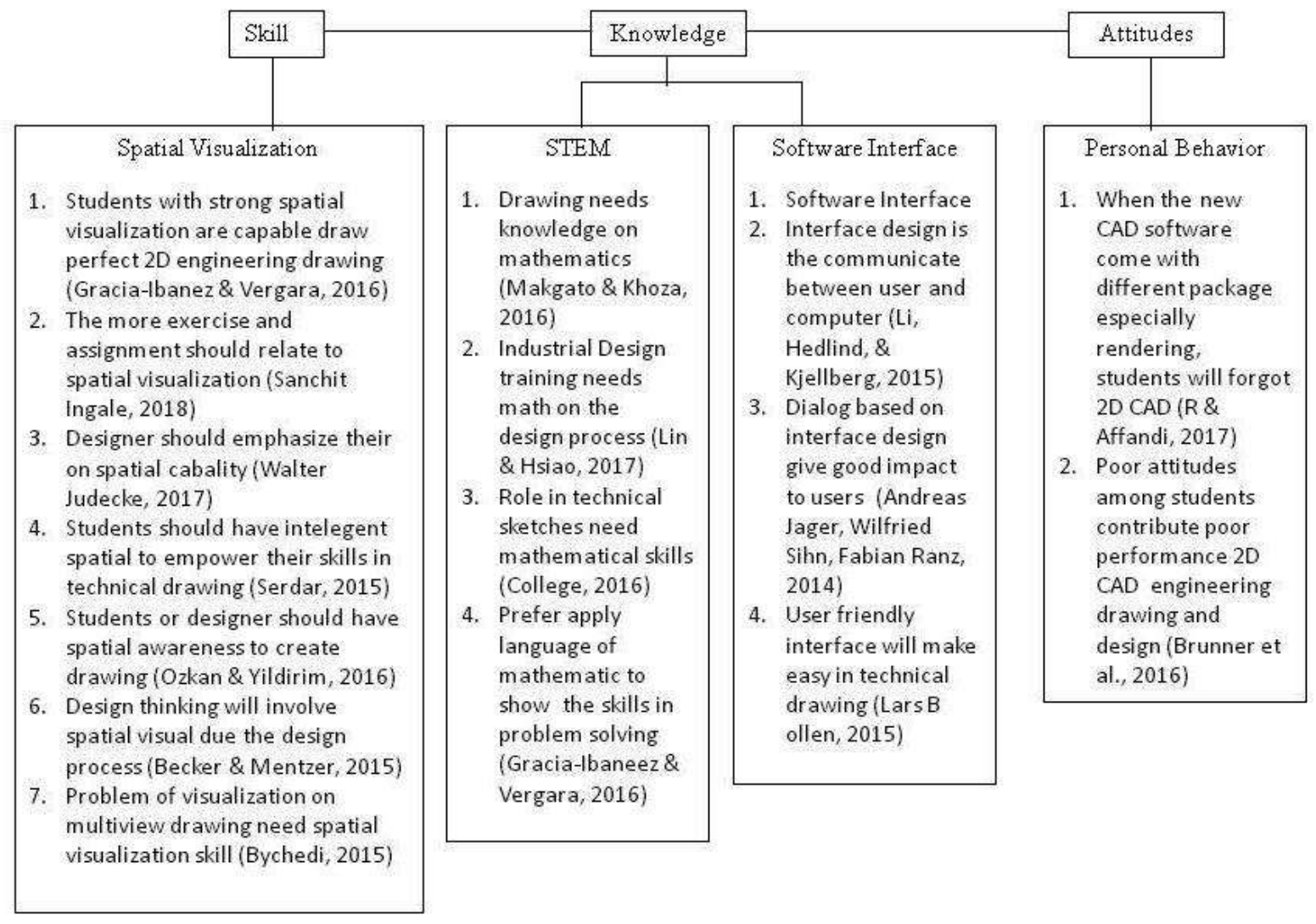

Figure 2. The Literature Review Analysis Framework

\section{Methodology}

This paper presents a list of identify problems and competencies required in producing 2D CAD engineering drawings from the stance of teaching and learning process. As such, a lecturer is one in-charge of teaching certain modules (Yixian, Qihua, Xuan, \& Kongde, 2014). Thus, the interview sessions held in this study involved a focus group comprised of four lecturers selected from four various institutions. These respondents were chosen, mainly because they taught subjects related to furniture and product design or industrial design courses.

From the literature review, a total of four areas had been identified that required improvement. With that, experienced instructors or lecturers who taught subjects related to furniture and product design had been selected as participants for data collection to further explore in case of any similar issues shared between those found in literature review and research findings.

Moreover, these selected lecturers have had experiences and teaching students from the lower competency is a norm among them. As such, the research design employed in this study is the qualitative method, in which Atlas Ti software program was applied to analyze the gathered data. Statements presented in italic font refer to responses provided by the respondents during the interview sessions. Besides, the five questions posed to the respondents during the interview, are listed below: 
INTERNATIONAL JOURNAL OF ACADEMIC RESEARCH IN BUSINESS AND SOCIAL SCIENCES Vol. 10, No. 2, Feb, 2020, E-ISSN: 2222-6990 @ 2020 HRMARS

1. Are any of your students weak in 2D CAD drawing?

2. Why are students weak in 2D CAD engineering at this present day?

3. What is the knowledge, skills, and attitudes required to produce good 2D CAD engineering drawing?

4. Do you think that $2 \mathrm{D}$ CAD is still relevant to Furniture and Product Design courses?

5. How can one improve the 2D CAD engineering drawing, learning and teaching process?

\section{Results and Discussion}

As a result, some respondents failed in providing answers in accordance to the questions given. Nevertheless, their feedback had been almost similar to that found in the literature review analysis. In fact, some added information was also offered, especially for the competency category. Furthermore, the themes and insights captured from the interview sessions were derived from the issues raised by the four selected respondents, who were lecturers for CAD subjects in the industrial design courses that focus on furniture and product design.

Table 1 Theme from Participant 1(P1)

\begin{tabular}{|l|l|}
\hline Theme 1 & $\begin{array}{l}\text { Reliable and affordable } \\
\text { software }\end{array}$ \\
\hline Theme 2 & $\begin{array}{l}\text { Lacking in technical thinking } \\
\text { skills }\end{array}$ \\
\hline Theme 3 & Mathematical knowledge \\
\hline
\end{tabular}

\section{Theme 1: Reliable and Affordable Software}

This theme depicts that vendors or small companies are still using the CAD software program mainly due to its low cost. However, P1 did not provide a direct answer for the question. Instead, he gave his opinion about the problems faced by students as he claimed that these students were unaware of the reality in the industrial setting. These students believed that the industry only applied advanced 3D CAD. This particular theme also highlights that 2D it is indeed good software to learn.

P1 claimed: "Yes we do have a few weak students. But CAD is a fundamental tool for engineering drawings and it is affordable. But there is more to 2D drawing. Therefore, some small companies do not apply the advances 3D CAD."

\section{Theme 2: Lacking in Technical Thinking Skill}

This theme elaborates the thinking skills, in which P1 opined that the existing advanced 3D CAD dictated preference among students towards aesthetic aspect more than the technical element. Hence, some essential requirements are needed to produce good drawings. This showed that the students disliked putting much thought. In addition, this theme is closely related to attitudes, where the personal perspective among students towards 2D CAD engineering drawing had been negative.

P1 stated: "This software is a fundamental tool and it is good to learn. If we know how to use this CAD software, we should not have any problem applying different software. Actually, the students 
INTERNATIONAL JOURNAL OF ACADEMIC RESEARCH IN BUSINESS AND SOCIAL SCIENCES

Vol. 10, No. 2, Feb, 2020, E-ISSN: 2222-6990 @ 2020 HRMARS

prefer other 3D CAD software because some software programs come along with rendering package. Therefore, students need not do double tasks. However, they must understand the theory of engineering drawing."

\section{Theme 3: Mathematical knowledge}

Theme 3 looks into the knowledge of fundamental technical drawing, which should be given more focus. Frankly, a majority of designing students dislike mathematics, as they find the subject dry. Instead, mathematics is a significant subject applied in engineering drawing due to involvement of measurement, thus cannot be dismissed by the students. Moreover, this very theme is associated to STEM knowledge and high order thinking skills. Thus, the present institutions should improvise and propose new lesson plans, where spatial visual skills and other high technical thinking elements are prioritized.

P1 claimed: "Well, the understanding of traditional engineering drawing must be strong before moving on to CAD, where they learn the use of engineering drawing tools. During class, they learn how to draw geometries, orthographic, and others. However, some dismiss the traditional style. Meanwhile, some others feel bored and get stressed due to their dislike towards calculation. Therefore, mathematical knowledge becomes a shortcoming. Therefore, I would like to suggest that the lesson plans must be improvised, where mathematics should be given more emphasis and drawing multiple views on engineering drawing is highlighted"

Table 2 Theme from Participant 2 (P2)

\begin{tabular}{|l|l|}
\hline $\begin{array}{l}\text { Theme } \\
1\end{array}$ & Lacking in technical thinking skills \\
\hline $\begin{array}{l}\text { Theme } \\
2\end{array}$ & Reliable for industry usage. \\
\hline $\begin{array}{l}\text { Theme } \\
3\end{array}$ & Lack of mathematical knowledge \\
\hline
\end{tabular}

\section{Theme 1: Lacking in Technical Thinking Skill}

This theme is similar to the second theme depicted by Participant 1 , which asserted that students faced problem in developing model due to incomplete engineering drawing. Moreover, spatial visual skills are an essential technical thinking skill. It is very unfortunate that fail in drawing which refer to their product design. Besides, they refused to refer and were weak to interpret the drawings due to poor model development process. This also denotes the attitudes exerted by the students' attitude, where they lacked technical thinking.

P2 answered: "CAD is the best software program that teaches students to think in a technical manner. However, students prefer the short cut way, where they don't want to think. Most of them are weak in drawing 2D multiple views or known as orthographic drawing. That's why they always have problems with the model development process due to incomplete drawing." 
INTERNATIONAL JOURNAL OF ACADEMIC RESEARCH IN BUSINESS AND SOCIAL SCIENCES

Vol. 10, No. 2, Feb, 2020, E-ISSN: 2222-6990 @ 2020 HRMARS

\section{Theme 2: Reliable for Industry Usage}

This theme portrays that the students do not understand the real work or the actual working environment. The furniture industry still employs CAD for both designing and manufacturing processes. Therefore, there is no reason to abandon the CAD.

P 2 stated: "The industry still applies CAD, especially for furniture design."

\section{Theme 3: Lack of Mathematical Knowledge and Spatial Visualization Problem}

This theme is almost similar to that mentioned by Participant 1. The students abhorred calculation. Besides, P2 added that spatial visualization is required for 2D CAD engineering drawing, especially orthographic drawing. Orthographic drawing is a very important 2D engineering drawing that functions as the main reference for model building. Therefore, the lecturer should embed more mathematical, spatial visual skills, and engineering aspects. For instance, P2 added that some students failed in distinguishing between the radius and diameter symbols for circle or arc.

P2 stated: "Before proceeding with CAD, they should have knowledge about math's, tolerance, and basic technical documentation. I know some students fear numbers, but they

are left with no choice. Perhaps, they are also weak in spatial visualization, which is a technical skill. They cannot imagine in 2D or 3D form, thus they face difficulty in producing good orthographic drawing. Orthographic drawing is very important because the designer or manufacture will read and interpret the drawing to build model. However, failure in applying the apt symbol for full circle and arc leads to poor model development. Hence, I agree that there is a relationship between such problem and competency. If we can identify the problem, then we better polish their competency for CAD application"

Table 3 Theme from Participant 3 (P3)

\begin{tabular}{|l|ll|}
\hline Theme 1 & Attitudes & \\
\hline Theme 2 & $\begin{array}{l}\text { Lack of critical and technical } \\
\text { thinking }\end{array}$ & software \\
\hline Theme 3 & $\begin{array}{l}\text { Understanding } \\
\text { interactiveness }\end{array}$ & \\
\hline
\end{tabular}

\section{Theme 1: Attitudes}

This theme depicts that even if the students preferred using software programs, their drawing would still be poor if they have behavioral issues, for instance, taking 2D engineering drawing lightly.

P3 claimed: "Although varied software programs are available in the market, the same drawing issues will persist if the students refuse to improve their attitude. Shortcuts just do not work." 
INTERNATIONAL JOURNAL OF ACADEMIC RESEARCH IN BUSINESS AND SOCIAL SCIENCES

Vol. 10, No. 2, Feb, 2020, E-ISSN: 2222-6990 ¿ 2020 HRMARS

\section{Theme 2: Lack of Critical and Technical Thinking}

This theme is related to the significance of sketching process, knowledge on technical and problemsolving skills. Moreover, students should solve measurement issues on paper before moving to digital.

P3 answered: "They like to take short cuts. Students should understand that engineering drawing is essential in CAD, and so, they must acquire the skill. Besides, learning the conventional methods enhances their technical skills, in training them to solve problems and to in ensuring that they would understand engineering drawing. If this is neglected, they can perhaps become careless and miss several important elements in drawing, such as hidden lines."

\section{Theme 3: Understanding Software Instructiveness}

This particular theme reflects the fact that the students lacked knowledge in using the software interface. They had problems reckoning menu, commands, and ways to plot a drawing. At times, they were unaware of soft software upgrade and changes in features, thus leading to bad engineering drawing.

P3 stated: "In my opinion and based on my experiences, students need to acquire skills for planning, gain knowledge about fundamental, technical drawing, as well as understand the interface and commands on CAD. However, when commands are involved, students need to learn and memorize all the menus embedded within the CAD. I always have students failing to the commands and never fail to do mistakes. Software upgrade is also an issue because some features may be altered. However, with passion, engineering drawing would not be a challenge."

Table 4 Theme from Participant 4 (P4)

\begin{tabular}{|l|l|}
\hline Theme 1 & Reliable for industry usage. \\
\hline Theme 2 & Attitudes \\
\hline Theme 3 & $\begin{array}{l}\text { Lack of critical and technical } \\
\text { thinking }\end{array}$ \\
\hline
\end{tabular}

\section{Theme 1: Reliable for Industry Usage}

This theme explains that the CAD is indeed useful for furniture design, hence reliable for the industry. In fact, this theme is similar to that depicted by P2.

P4 stated: "So far, we still teach CAD because we have furniture design. In addition, we can use it for product design as well."

\section{Theme 2: Attitudes}

This theme is recurring primarily because the students did not display interest to practice using the software, even for engineering drawing. Such lack of interest and lack of exploration are the reasons behind their failure in successfully applying the software program. 
INTERNATIONAL JOURNAL OF ACADEMIC RESEARCH IN BUSINESS AND SOCIAL SCIENCES

Vol. 10, No. 2, Feb, 2020, E-ISSN: 2222-6990 @ 2020 HRMARS

P4 claimed: "But what I can see is that students do not explore much or do revision after the CAD class. Actually, they should practice because practice makes perfect."

\section{Theme 3: Lack of Critical and Technical Thinking}

This theme was mentioned by all respondents pertaining to the fact that the students lacked in technical thinking and material study. Material study is not reflective of the material itself, but knowledge on STEM as well. This theme is inclusive of drawing measurement and tolerance. If mistakes are made for measurement, additional cost is incurred for prototype and time is wasted. However, STEM is very technical, thus viewed as dry and uninteresting among students. Nonetheless, lecturers also put their effort in devising new strategies to teach these subjects.

P4 stated: "Technical skill is needed for engineering drawing. Any CAD software needs this technical skill. Hence, students should know the form and the measurement of their design. Students should also know how to analyze an engineering drawing. Measurement is very important. It involves time and expenses to produce a prototype. Meanwhile, knowledge of command in 2D $C A D$ is related to knowledge of conventional engineering drawing. For instance, defining tangent in a drawing. In the conventional approach, one applies a compass; whereas in 2D CAD, command tangent, tangent, and radius (ttr) are employed, to name a few. Therefore, it solves problems related to drawing. Yes, knowledge of interactiveness and the element of STEM should be included as compulsory subjects, as well as part of competency for 2D CAD engineering drawing. Moreover, as STEM embeds high order thinking, the teaching style is always improvised."

\section{Conclusion}

This study identified a list of the required competencies for successful 2D CAD engineering drawing among industrial design students majoring in furniture and product design. The results retrieved are not only beneficial for design educators or institutions, but also in matching the developmental trend for industry and satisfying needs of students. As such, four varied categories of competency had been explored in this study. Some useful findings are summarized in the following:

1. Spatial visualization skills are an important skill in engineering fields. This skill requires the ability of the human brain to draw, keep, retrieve, and transform 3D drawing to 2D or otherwise. Besides, spatial ability is related to the cognitive load of memory and it is also a skill required for drawing with multiple view, sectional view, and orthographic (Guney, 2015). Skills train students to interpret drawing with appropriate lines, for instance, detecting hidden lines that differ from object lines (Burvill et al., 2016; Katsioloudis, Jovanovic \& Jones, 2014).

2. STEM knowledge is a dire lesson in engineering drawing. In fact, engineering drawing involves calculation and measurement (Hafizan et al., 2017), as well as science, technology, and engineering elements. An example is including material information within the drawing. In fact, all analyses are performed within the engineering drawing. As such, cost and the time are saved for prototype process. 
INTERNATIONAL JOURNAL OF ACADEMIC RESEARCH IN BUSINESS AND SOCIAL SCIENCES

Vol. 10, No. 2, Feb, 2020, E-ISSN: 2222-6990 @ 2020 HRMARS

3. The software interface knowledge is related to the system and the features. All features embedded within a software program must be clear, as it involves the human thinking process (Becker \& Mentzer, 2015). Annually, these software programs are upgraded towards improving the design process to be more accurate, productive, and efficient, besides allowing for a more gradual transition (Repenning, 2016). Hence, instructors, institutions, students, and the industry itself, should be aware of such software upgrade.

4. Personal behavior is closely associated to one's perception and character towards becoming more positive and to think creatively. Creativity thinking is not only for students, but also for instructors to teach 2D CAD in a more fun-filled manner. Creative teaching should attract students to further learn about a subject matter. As such, the students should have interest in exploring more software programs and engineering drawing. Awareness about industry also should motivate these students to perform better in 2D CAD engineering drawing (Kim \& Lee, 2014; Newton, 2015).

The results obtained from this study showed that the performance of students on 2D CAD engineering drawing had been limited to several competencies. Whether these industrial design students are educated as generalists or specialists, they should become reflective practitioners in order to adapt to the changes and challenges that lay in the future. Competency 2D engineering still needed due to getting a job for the industry. The majority company still apply 2D CAD engineering drawing software. Therefore, focus on 2D engineering still important until today even there is advance 3D engineering drawing software.

\section{References}

Jager, A., Sihn, W., Ranz, F. V. H. (2014). Implications for learning factories from industry 4.0 challenges for the human factor in future production scenarios. TUWien-ESB-Fraunhofer Austria.

Becker, K., \& Mentzer, N. (2015). Engineering design thinking: High school students' performance and knowledge. In Proceedings of 2015 International Conference on Interactive Collaborative Learning, ICL 2015 (Vol. 104, pp. 5-12). Retrieved from https://doi.org/10.1109/ICL.2015.7318218

Brunner, C. B., Ullrich, S., Jungen, P., \& Esch, F.-R. (2016). Product \& brand management impact of symbolic product design on brand evaluations introduction; The importance of product design for brand evaluations. Journal of Product \& Brand Management, 25(3), 307-320. Retrieved from http://dx.doi.org/10.1108/JPBM-06-2015-0896.

Burvill, C., Field, B., Abdullah, Z., \& Alias, M. (2016). Problem-solving with industrial drawings : Supporting formal graphics language development for Malaysian engineering graduates. International Journal of Engineering Education, 32(5), 2172-2183.

Bychedi, J. M. (2015). Technical Drawing/Graphic Skills Acquisition For Teaching And Learning And Challenges In Technology Education. Journal of Science Technology \& Education ( JOSTE ), 3(3).

Chouhan, V. S., \& Srivastava, S. (2014). Understanding competencies and competency Modeling A Literature Survey. IOSR Journal of Business and Management, 16(1), 14-22. Retrieved from 
INTERNATIONAL JOURNAL OF ACADEMIC RESEARCH IN BUSINESS AND SOCIAL SCIENCES

Vol. 10, No. 2, Feb, 2020, E-ISSN: 2222-6990 @ 2020 HRMARS

https://doi.org/10.9790/487x-16111422.

College, P. C. (2016). Computer Aided Drafting and Design Program Review January 2016. Retrieved from http://www.pcc.edu/resources/academic/core-outcomes/mapping-index.html.

Efer, O. O.F. (2017). Industrial design: The roles and factors of aesthetics, modeling, styling, product brand and branding in design. Review of Artistic Education, 14(1), 186-199. Retrieved from https://doi.org/10.1515/rae-2017-0024

Eteli, I., \& Eniekenemi, E. (2016). Effect of AutoCAD software in teaching isometric and oblique drawing among female students in Federal Science Technical College Tungbo, Bayelsa State. International Journal of Education and Evaluation ISSN, 2(2), 2489-73.

Gracia-Ibaneez, V., \& Vergara, M. (2016). Applying action research in CAD teaching to improve the learning experience and academic level. International Journal of Educational Technology in Higher Education, 13(1), 1-13. Retrieved from https://doi.org/10.1186/s41239-016-0010-5

Gracia-Ibáñez, V., \& Vergara, M. (2016). Applying action research in CAD teaching to improve the learning experience and academic level. International Journal of Educational Technology in Higher Education (Vol. 13, pp. 1-13). Retrieved from https://doi.org/10.1186/s41239-0160010-5

Guney, D. (2015). The Importance of Computer-aided Courses in Architectural Education. In Procedia - Social and Behavioral Sciences (Vol. 176, pp. 757-765). Elsevier B.V. https://doi.org/10.1016/j.sbspro.2015.01.537

Hafizan, E., Shahali, M., \& Halim, L. (2017). STEM learning through engineering design : Impact on middle secondary students ' interest towards STEM. Journal of Mathematics Science and Technology Education, 8223(5), 1189-1211. https://doi.org/10.12973/eurasia.2017.00667a

Katsioloudis, P., Jovanovic, V., \& Jones, M. (2014). A Comparative Analysis of Spatial Visualization Ability and Drafting Models for Industrial and Technology Education Students. Journal of Technology Education, 26(1), 89-101.

Kim, K., \& Lee, K. (2014). Industrial designers and engineering designers ;Causes of conflicts , resolving strategies, and perceived image of each other. In Proceedings of DRS 2014.

Lars B ollen, H. G. (2015). Drawings in computer supported collaborative learning - empirical and technical results. Computing and Informatics, 34, 559-587.

Li, Y., Hedlind, M., \& Kjellberg, T. (2015). Usability evaluation of CADCAM: State of the art. In Procedia CIRP (Vol. 36, pp. 205-210). Retrieved from https://doi.org/10.1016/j.procir.2015.01.053

Lin, H.-H., \& Hsiao, S.-W. (2017). A study of the evaluation of products by industrial design students. Eurasia Journal of Mathematics, Science and Technology Education, 14(1), 239-254. Retrieved from https://doi.org/10.12973/ejmste/79652

Makgato, M., \& Khoza, S. D. (2016). Difficulties of student teachers in the engineering graphics and design course at a south african university: Snapshot on sectional drawing. Eurasia Journal of Mathematics, Science and Technology Education. Retrieved from https://doi.org/10.12973/eurasia.2016.1220a

Özkan, A., \& Yildirim, K. (2016). Comparison of conventional and computer-aided drafting methods from the view of time and drafting quality. Eurasian Journal of Educational Research, (62), 257-272. Retrieved from https://doi.org/10.14689/ejer.2015.58.2

R, I. I. M., \& Affandi, H. M. (2017). A case study of AutoCAD 2D engineering drawing performance 
INTERNATIONAL JOURNAL OF ACADEMIC RESEARCH IN BUSINESS AND SOCIAL SCIENCES

Vol. 10, No. 2, Feb, 2020, E-ISSN: 2222-6990 @ 2020 HRMARS

among furniture and product design ( BFPD ) Students . In Proceedings of International Conference on Education ICEDU 2017. Kuala Lumpur.

Newton, R. (2015). AutoCAD alternatives are alive and well in product design Graebert: Millions of 2D CAD seats. Retrieved from http://www.digitaleng.news/de/autocad-alternatives-are-aliveand-well-in-product-design/

Repenning, A. (2016). Transforming " hard and boring " into " accessible and exciting ". IEEE Xplore: Computer, 46(6). Retrieved from

https://sgd.cs.colorado.edu/wiki/images/9/91/Repenning_NordiCHI_2016.pdf

Ingale, S. A. S. \& D. B. (2018). Cad platform independent software for automatic grading of technical drawings. In ASME 2017 International Design Engineering Technical Conferences and Computers and Information in Engineering Conference IDETC/CIE 2017 (pp. 1-7). Ohio.

Serdar, T. (2015). Enhancing spatial visualization skills in engineering drawing course. In 122nd ASEE Annual Conference \& Exposition (pp. 26.663.1-26.663.12).

Stefanova, S. A., \& Vasileva, T. K. (2014). Trialogical approach to knowledge practices in CAD education. Annual Journal Of Electronics, 150-153.

Jüdecke, W. P. K. (2017). Textbook for Vocational Training - Engineering Drawing Metal (1st ed.). Berlin.

Yixian, D., Qihua, T., Xuan, D., \& Kongde, H. (2014). CAD/CAM courses integration of theoretical teaching and practical training. Procedia - Social and Behavioral Sciences, 116, 4297-4300. Retrieved from https://doi.org/10.1016/j.sbspro.2014.01.935 